\title{
LAS MATEMATIKA BERBASIS AKTIVITAS KREATIF DALAM PENINGKATAN AKTIVITAS BELAJAR SISWA
}

\author{
Suriyani $^{1 *}$, Laili Habibah Pasaribu ${ }^{2}$ \\ ${ }^{1,2}$ Pendidikan Matematika STKIP Labuhan Batu, Jalan Sisingamangaraja Nomor 126 A Km. 3,5 Tapa \\ Rantauprapat Sumatera Utara Indonesia \\ *email: suriyanistkiplabuhanbatu@gmail.com
}

Received: 13 Maret 2019 Accepted: 1 Juni 2019 Published: 30 Juni 2019

\begin{abstract}
Abstrak
Fokus penelitian ini adalah mengembangkan instrumen pembelajaran berupa LAS berbasis aktivitas kreatif untuk digunakan dalam pembelajaran di kelas dan menganalisis hubungan penggunaan LAS tersebut pada peningktan aktivitas kreatif siswa. Analisis validasi soal dalam kategori valid dengan indeks thitung >tTabel yaitu pada masing-masing item soal (1a) 5,18 > 2,0; (1b) 3,88 > 2,04; (2a) 2,84 > 2,04; (2b) 5,18>2,04; (3) 5,05> 2,04. Dari aspek realibilitas diperoleh indeks r11 = 0,53 yaitu kategori sedang; daya beda soal memiliki indeks rata-rata 0,365 yaitu baik, dan tingkat kesukaran soal memiliki indeks yang beragam sehingga soal yang disajikan sudah cukup baik dan layak untuk digunakan dalam pembelajaran di sekolah yang ingin mengedepankan aktifitas kreatif siswa. Berdasarkan hasil analisis perbedaan rata-rata antara kemampuan berpikir kretif siswa sebelum dan sesudah menggunakan LAS berbasis kreatif diperoleh hasil bahwa peningkatan aktivitas belajar siswa meningkat signifikan dengan melihat indeks Gain sebelum dan sesudah menggunakan LAS sebesar 3,157.
\end{abstract}

Kata kunci: lembar aktivitas siswa, aktifitas kreatif

\begin{abstract}
The focus of this research is to develop learning instruments in the form of LAS based on creative activities to be used in classroom learning and analyze the relationship between the use of LAS in improving students' activity. Validation analysis of the questions was in a valid category with an index of $t_{\text {count }}>t_{\text {table }}$ that was 4.426>2.04; from the aspect of reliability, the index $r_{11}=0.53$ is obtained, namely the medium category; The difference between questions has an average index of 0.365 which is good, and the difficulty level of the questions has a diverse index so that the questions presented are good enough and suitable for use in learning in schools that want to prioritize students' activities. Based on the results of the analysis of the average difference between students 'creative thinking skills before and after using creative based LAS, it was found that the improvement of students' activity increased significantly by looking at the Gain index before and after using LAS of 3.157.
\end{abstract}

Keywords: student activity sheet, creative asctivity

(C) 2019 LPPM IKIP PGRI Pontianak, Indonesia

\section{PENDAHULUAN}

Dalam pembelajaran matematika pembahasan tentang kreatifitas sering sekali diabaikan karena dianggap bukan kemmapuan yang mempengaruhi kemampuan bermatematika siswa. 
Apakah terdapat kreativitas dalam matematika? Menurut Pehnoken (Mahmudin, 2010), kreativitas tidak hanya terjadi pada bidang-bidang tertentu, seperti seni, sastra, atau sains, melainkan juga ditemukan dalam berbagai bidang kehidupan, termasuk matematika. Padahal dalam matematika kreativitas sangat diperlukan, memang bukan dalam bentuk karya seni, musik, lagu atau lukisan akan tetapi lebih kepada cara proses berpikir siswa. Kemapuan berpikir kreatif memungkinkan siswa untuk memiliki kemampuan berpikir luwes dalam menyelesaikan masalah matematika sehingga siswa mampu menemukan berbagai cara dan solusi dalam menyelesaikan soal.

Kreativitas sering sekali dianggap tidak penting oleh para guru atau praktisi matematika karena menurut mereka matematika adalah kemampuan menghafal rumus dan menyelesaikan soal berdasarkan rumus. Para matematikawan berpendapat bahwa kemampuan fleksibelitas yang merupakan indikator kemampuan berpikir kreatif merupakan kemampuan yang perlu dimiliki siswa dalam memecahkan masalah matematika.Pentingnya kreativitas dalam matematika dikemukakan oleh Bishop (Mahmudin, 2010) yang menyatakan bahwa seseorang memerlukan dua keterampilan berpikir matematis, yaitu berpikir kreatif yang sering diidentikkan dengan intuisi dan kemampuan berpikir analitik yang diidentikkan dengan kemampuan berpikir logis. Sementara Kiesswetter (Mahmudin, 2010). Selanjutnya Suhendri (Trisnawati, et al., 2018) menyatakan bahwa rasa percaya diri atau self-confidence merupakan suatu sikap mental positif dari seorang individu yang memposisikan atau mengkondisikan dirinya dapat mengevaluasi tentang diri sendiri dan lingkungannya sehingga merasa nyaman untuk melakukan kegiatan dalam upaya mencapai tujuan yang direncanakan.

Berdasarkan uraian pentingnya kemapuan berpikir kreatif diatas perlu dikembangkan suatu instrumen untuk membuat siswa terbiasa mengasah kemampuan berpikir kreatifnya dan memaksimalkan aktifitas siswa di dalam kelas sehingga pembelajaran bisa menjadi lebih inovatif dan menyenangkan seperti Lembar Aktivitas Siswa (LAS). LAS adalah salah satu perangkat pembelajaran yang berhubungan langsung dengan siswa. Dalam pembelajaran siswa sering kali dihadapkan dengan masalaha-masalah yang disajikan dalam bentuk LAS. Untuk itu sangat tepat rasanya jika perlu dikembangkan sebuah LAS yang berbasis aktifitas kreatif siswa untuk mengasah kemampuan berpikir kreatif siswa. Tujuannya tidak lain adalah untuk mengembangkan kegiatan pembelajaran matematika sehingga tidak 100\% bergantung pada kehadiran guru di kelas. Dalam LAS ini nantinya akan dirancang masalah-masalah matematika 
yang bisa memancing kemampuan berpikir luwes, lancar, original, dan terperinci. Masalah yang diberikan akan dikembangkan sebaik-baiknya dengan mempertimbangkan indikator kemampuan berpikir kreatif, LAS yang telah dikembangkan juga harus diuji kenadalannya dengan uji coba langsung pada siswa dan dinilai kelayakannya oleh ahli yaitu guru dan dosen matematika. Selama ini telah banyak dikembangkan LAS oleh para peneliti namun hanya berpokus pada peningkatan kemampuan berpikir siswa, namun pada kesempatan ini peneliti mencoba mengembangkan instrumen LAS yang memfasilitasi siswa untuk belajar dengan aktifitas kreatif. Aktifitas kreatif yang dimaksud adalah dalam menemukan suatu solusi atau konsep baru siswa diajak untuk menemukannya sendiri dengan uji coba dan praktik.

\section{METODE}

Penelitian yang akan dilakukan adalah penelitian pengembangan dengan mengadopsi model pengembangan Borg dan Gall. Penelitian pengembangan bertujuan mengembangkan produk berupa perangkat pembelajaran berdasarkan uji coba untuk kemudian direvisi sampai menghasilkan produk yang bernilai baik dan layak.Produk yang dikembangkan oleh peneliti adalah Lembar Aktivitas Siswa (LAS) matematika berbasis aktivitas kreatif siswa.

Populasi penelitian ini adalah seluruh siswa MTs Negeri Rantau Prapat Tahun Pembelajaran 2017/2018 dengan menggunakan teknik penarikan sampel purposive sampling. Selain itu peneliti juga menggunakan rumus Slovin untuk menentukan besarnya jumlah sampel. Asumsi penentuan besar sampel dengan menggunakan rumus Slovin (Prasetyo \& Jannah, 2005), yaitu seperti pada Persamaan 1.

$$
n=\frac{N}{1+N(e)^{2}}
$$

Berdasarkan Persamaan 1 dapat diketahui bahwa $n$ adalah ukuran sampel, $N$ adalah ukuran populasi dan $e$ adalah persen kelonggaran ketidaktelitian karena kesalahan pengambilan sampel yang masih dapat ditolerir atau diinginkan misalnya 5\%.

Prosedur penelitian pengembangan ini menggunakan model pengembangan pengembangan LAS matematika berbasis aktivitas kreatif. Model pengembangan terdiri dari 4 tahap pengembangan yaitu: Pendefinisian (Define), Perancangan (Design), Pengembangan (Develop), Penyebaran (Desseminate). Namun, peneliti tidak menerapkan tahap penyebaran sehingga penelitian ini hanya sampai tahap pengembangan, karena peneliti hanya ingin membuat 
suatu produk instrumen pembelajaran yang apik dan layak sehingga dikemudian hari dapat dikaji kembali oleh peneliti lain yang ingin fokus dalam pengembangan instrumen pembelajaran khususnya LAS.

Instrumen yang digunakan dalam penelitian ini berupa lembar validitas LAS, instrumen ini digunakan untuk mengukur validitas LAS yang akan dilakukan oleh validator. Adapun yang menjadi validator yaitu satu orang dosen pendidikan matematika dan satu guru matematika. Selain lembar validasi digunakan pula tes kemampuan berpikir kreatif untuk mengukur kemampuan berpikir kreatif siswa, dan lembar observasi aktivitas siswa, instrument ini digunakan untuk mendapatkan data tentang aktivitas dan respon siswa selama proses pembelajaran berlangsung.

LAS yang telah dibuat akan diuji kehandalannya dengan melewati beberpa analisis berupa analisis kevalidan, reliabilitas, daya beda dan tingkat kesukaran. Kevalidan instrumen yang dikembangkan melalui tahap pemberian skor untuk setiap item dengan jawaban "sangat" sesuai skor (5), "sesuai” skor (4), “cukup” skor (3), "kurang” skor (2), dan "tidak sesuai” skor (1). Menjumlahkan skor total tiap validator untuk setiap aspek menggunakan Persamaan 2 (Sugiyono, 2013).

$$
\bar{V}=\frac{\sum_{i=1}^{n} x_{i}}{n}
$$

Mencari rata-rata tiap aspek dari semua validator dan menghitung nilai validasinya menggunakan Persamaan 2 (Sugiyono, 2013).

$$
\bar{M}_{V}=\frac{\sum_{i=1}^{n} \bar{V}_{t}}{n}
$$

Selanjutnya membandingkan rata-rata total validitas $\bar{M}_{V}$ dengan kriteria kevalidan perangkat pembelajaran LAS matematika berbasis aktivitas kreatif berdasarkan kriteria validasi tes pada Tabel 1.

Reliabilitas instrumen dihitung menggunakan rumus Alpha Cronbach (Arikunto, 2008) dan dikategorikan berdasarkan kriteria reliabitas oleh Nugraha (2015). Daya pembeda soal dan tingkat kesukaran soal dihitung menggunakan rumus berdasarkan Wahidmurni (2010). 
Tabel 1. Kriteria Validasi Tes

\begin{tabular}{cc}
\hline Interval Skor & Kategori \\
\hline $\mathbf{0} \leq \bar{x}<\mathbf{1 , 8}$ & Tidak Valid \\
$\mathbf{1 , 8} \leq \bar{x}<\mathbf{2 , 6}$ & Kurang Valid \\
$\mathbf{2 , 6} \leq \bar{x}<\mathbf{3 , 4}$ & Cukup Valid \\
$\mathbf{3 , 4} \leq \bar{x}<\mathbf{4 , 2}$ & Valid \\
$\mathbf{4 , 2} \leq \bar{x}<\mathbf{5}$ & Sangat Valid \\
\hline
\end{tabular}

Tahap selanjutnya seteah LAS diuji cobakan pada kelas eksperimen, dan telah diberikan tes kemampuan berpikir kreatif pada kelas eksperimen dan kontrol maka dilakukan uji Gain Ternormalisasi. Melalui tahap ini dapat diketahui besar peningkatan berpikir kreatif dikumpulkandari sebelum sampai setelah mendapat pembelajaran baik yang mendapat pembelajaran dengan mengaplikasikan penggunaan LAS berbasis aktivitas kreatif maupun maupun tanpa menggunakan LAS. Gain ternomalisasi $(g)$ ini diperkenalkan oleh Hake dan secara sederhana merupakan gain absolut dengan gain maksimum yang mungkin (ideal), dengan menggunakan Persamaan 3 (Bao, 2006).

\section{HASIL DAN PEMBAHASAN}

Pada bagian ini akan dideskripsikan hasil penelitian yang berhubungan dengan upaya pengembangan instrumen pembelajaran berupa Lembar Aktivitas Siswa berbasis Aktivitas Kreatif dan hubungannya terhadap peningkatan kemampuan berpikir kreatif siswa. Pada tahap awal peneliti menguji kehandalan instrumen dengan menguji validasi, reliabitas, Daya Beda, dan Tingkat Kesukaran Instrumen LAS pada validator Ahli yang meliputi satu orang guru bidang Studi Matematika dan Dosen Pendidikan Matematika. Lewat hasil analisis kelayakan yang dilakukan oleh dua orang validator ini diperoleh hasil seperti yang terlihat pada Tabel 2. Berdasarkan tiga aspek yaitu format penulisan, bahasa, dan isi oleh validator diperoleh nilai 4,35 yang dapat diartikan bahwa Lembar Aktivitas Siswa yang dikembangkan masuk dalam kategori baik.

Selanjutnya peneliti membagikan LAS yang telah dirancang sebelumnya kepada 35 siswa kelas VIII MTS N Rantauprapat. Lembar Aktivitas Siswa ini berisi rangkaian soal dan penugasan yang menuntut siswa untuk beraktivitas kreatif. Selain membagikan LAS peneliti juga membagikan alat dan bahan yang bisa digunakan oleh siswa untuk memecahkan setiap masalah 
yang disajikan di dalam LAS. Dari LAS yang telah dikerjakan oleh siswa peneliti melakukan analisis tahap awal diperoleh hasil seperti pada Tabel 3.

Tabel 2. Hasil uji kehandalan ahli

\begin{tabular}{|c|c|c|c|c|c|c|c|}
\hline \multirow[t]{2}{*}{ No } & \multirow[t]{2}{*}{ Aspek Yang Dinilai } & \multicolumn{5}{|c|}{$\begin{array}{l}\text { Banyak validator memberi } \\
\text { nilai }\end{array}$} & \multirow[t]{2}{*}{ Rata-Rata } \\
\hline & & 1 & 2 & 3 & 4 & 5 & \\
\hline \multirow[t]{4}{*}{1} & Format & & & & & & \\
\hline & a. Kejelasan pembagian materi & 0 & 0 & 0 & 2 & 0 & 4,00 \\
\hline & b. Pengaturan tata letak & 0 & 0 & 0 & 2 & 0 & 4,00 \\
\hline & c. Jenis dan ukuran huruf yang sesuai & 0 & 0 & 0 & 0 & 2 & 5,00 \\
\hline \multirow[t]{5}{*}{2} & Bahasa & & & & & & \\
\hline & a. Kebenaran tata bahasa & 0 & 0 & 0 & 0 & 2 & 5,00 \\
\hline & b. Kesederhanaan struktur kalimat & 0 & 0 & 0 & 2 & 0 & 4,00 \\
\hline & c. Kesederhanaan arahan & 0 & 0 & 0 & 0 & 2 & 5,00 \\
\hline & d. Sifat komunikatif bahasa yang digunakan & 0 & 0 & 0 & 2 & 0 & 4,00 \\
\hline \multirow[t]{8}{*}{3} & Isi & & & & & & \\
\hline & a. Kesesuain dengan tingkat kognitif siswa & 0 & 0 & 0 & 0 & 2 & 5,00 \\
\hline & b. Dikelompokkan dalam bagian-bagian yang logis & 0 & 0 & 0 & 2 & 0 & 4,00 \\
\hline & c. Kesesuaian dengan silabus & 0 & 0 & 0 & 2 & 0 & 4,00 \\
\hline & $\begin{array}{l}\text { d. Kesesuaian dengan pembelajaran matematika } \\
\text { dengan pendekatan Open-Ended }\end{array}$ & 0 & 0 & 0 & 2 & 0 & 4,00 \\
\hline & e. Metode penyajian materi & 0 & 0 & 0 & 2 & 0 & 4,00 \\
\hline & f. Kelayakan kelengkapan belajar & 0 & 0 & 0 & 1 & 1 & 4,50 \\
\hline & g. Kesesuaian alokasi waktu yang digunakan & 0 & 0 & 0 & 1 & 1 & 4,50 \\
\hline \multicolumn{2}{|c|}{ Rata-Rata } & & & & & & 4,35 \\
\hline
\end{tabular}

Tabel 3. Skor Siswa berdasarkan LAS

\begin{tabular}{|c|c|c|c|}
\hline Nilai & Kategori & Jumlah siswa & Persentase \\
\hline $0-35$ & Rendah & 3 & $8,58 \%$ \\
\hline $36-75$ & Sedang & 24 & $68,57 \%$ \\
\hline $76-100$ & Tinggi & 8 & $22,85 \%$ \\
\hline \multicolumn{2}{|c|}{ Total } & 35 & $100 \%$ \\
\hline
\end{tabular}

Dengan menganalisis tiap butir soal yang ada dalam LAS diperoleh hasil Validitas, Realibilatas, Daya Beda, dan Tingkat Kesukaran diperoleh hasil seperti pada Tabel 4.

Tabel 4. Validasi LAS

\begin{tabular}{ccccc}
\hline Butir soal & $r_{x y}$ & $t_{\text {hitung }}$ & $t_{\text {tabel }}$ & Interpretasi \\
\hline 1.a & 0,67 & 5,18 & 2.04 & Valid \\
1.b & 0,56 & 3,88 & 2.04 & Valid \\
2.a & 0,44 & 2,84 & 2.04 & Valid \\
$\mathbf{2 . b}$ & 0,67 & 5,18 & 2.04 & Valid \\
$\mathbf{3}$ & 0,66 & 5,05 & 2.04 & Valid \\
\hline
\end{tabular}


Dari Tabel 4 diperoleh hasil bahwa pada tahap Uji Coba tiap item soal yang ada di dalam LAS telah Valid. Untuk Hasil uji Realibilitas diperoleh indeks $r_{11}=0,53$ artinya tngkat realibilitas soal dalam LAS tersebut dalam kategori sedang.

Dari analisis uji kehandalan tes yang telah dilakukan tersebut dapat dilihat bahwa soalsoal yang disajikan dalam LAS yang dikembangkan oleh peneliti dengan memperhatikan aspek aktivitas kreatif siswa telah memenuhi syarat dan layak digunkan dalam pembelaaran matematika di sekolah. Dari aspek validasi soal-soal tersebut sudah memenuhi ketepatan tujuan soal tersebut dibuat sesuai dengan indikator materi ajar. Dari aspek relib tes tersebut masuk dalam kategori sedang sehingga kapan pun soal tersebut digunakan akan menggambarkan tingkat hasil yang relatif sama. Dari aspek daya beda soal tersebut masuk dalam kategori baik untuk dapat membedakan tingkat kemampuan siswa. Dari aspek tingkat kesukaran soal yang disajikan sudah memiliki tingkat kesukaran yang beragam dari mudah, sedang, dan tinggi.

LAS yang telah dikembangkan kemudian digunakan dalam pembelajaran di kelas. Setelah itu dilakukan analisis terhadsp peningktan kemampuan berpikir kreatif siswa yang belajar dengan menggunakan LAS tersebut dibanding dengan kelas yang tidak menggunakan LAS, hasilnya disajikan pada Gambar 1.

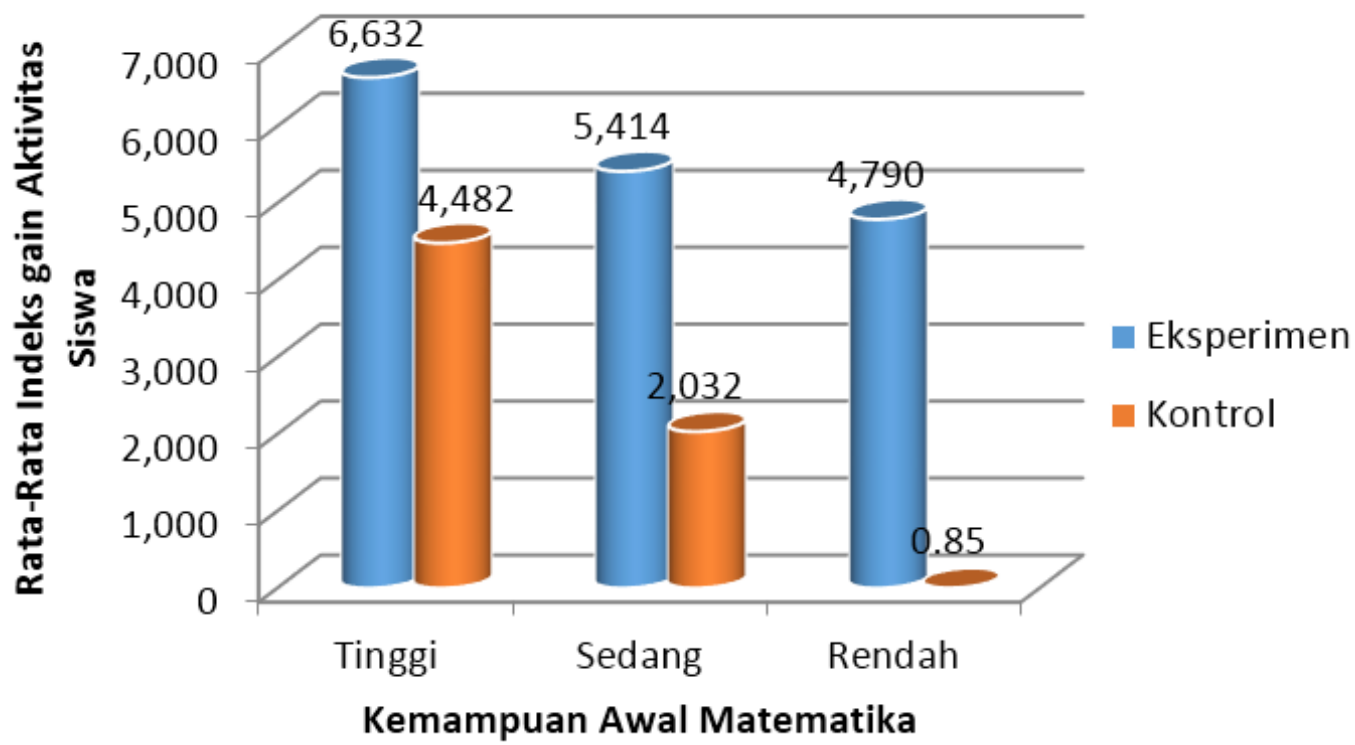

Gambar 1. Perbedaan indeks gain aktivitas siswa kelas kontrol dan eksperimen 
Dari Gambar 1 dapat dilihat bahwa aktivitas siswa yang menggunakan LAS berbasis aktifitas kreatif lebih baik dibanding dengan yang tidak menggunakan LAS. Dengan perbedaan rata-rata peningkatannya pada kelompok kemampuan tinggi, sedang, rendah adalah 3,157.

Berdasarkan hasil pengumpulan data serta analisis yang pada data yang ada diperoleh bahwa rata-rata hasil pretest kemampuan berpikir kreatif matematis pada kelas eksperimen, yaitu kreatif yang telah dikembangkan sebesar 3,831, sedangkan pada kelas kontrol, yaitu kelas yang menggunakan pembelajaran konvensional sebesar 2,191. Di samping itu, rata-rata hasil postes kemampuan berpikir kreatif pada kelas eksperimen sebesar 9,213, sedangkan pada kelas kontrol sebesar 4,561. Hal ini menunjukkan bahwa terdapat peningkatan kemampuan berpikirkreatif matematis pada kelas eksperimen dan kelas kontrol.

Untuk mengukur besar peningkatan kemampuan berpikir kreatif matematis dilakukan perhitungan indeks gain pada kelas keperimen dan kelas kontrol dan diperoleh rata-rata indeks gain hasil tes kemampuan berpikirkreatifmatematis pada kelas eksperimen sebesar 5,190, sedangkan pada kelas kontrol sebesar 2,261, sehingga peningkatan kemampuan berpikir kreatif matematis pada kelas ekperimen lebih tinggi daripada kelas kontrol. Dengan kata lain dengan menggunakan LAS berbasis aktivitas yang telah dikembangkan oleh peneliti dapat meningkatkan kemampuan berpikir kreatif siswa secara signifikans dengan rata-rata indeks gain-nya adalah 3,157. Dengan demikian hasil penelitian ini sejalan dengan teori belajar yang dikemukakan oleh Bruner bahwa dalam proses belajar anak sebaiknya diberi kesempatan untuk memanipulatif benda-benda (alat peraga) melalui alat peraga yang ditelitinya itu, anak akan melihat langsung bagaimana ketertautan dan pola struktur yang terdapat dalam benda yang diperhatikannya itu (Trianto, 2011). Selain itu lewat penelitian Nuraini (2012) menunjukkan bahwa peningkatan kemampuan berpikir kreatif matematis siswa yang mendapat pembelajaran matematika dengan pembelajaran berbasis aktivitas siswa lebih tinggi daripada siswa yang mendapat pembelajaran konvensional. Hal ini disebabkan karena pada pembelajaran matematika dengan mengutamakan aktivitas siswa memiliki kesempatan untuk menginvestigasi berbagai strategi dan cara yang diyakininya sesuai dengan kemampuan mengelaborasi permasalahan. Penelitian lain yang dilakukan oleh Purwasih dan Suryaningsih (2017) menyatakan bahwa peningkatan kemampuan berpikir kreatif matematika siswa yang mengikuti pembelajaran matematika dengan menggunakan pembelajaran berbasis masalah (PBM) lebih baik daripada siswa yang mendapat pembelajaran biasa; dan self-concept siswa yang mendapat pembelajaran matematika dengan 
menggunakan PBM lebih baik daripada siswa yang memperoleh pembelajaran biasa yang tergolong kualifikasi sedang. Dalam penelitian ini masalah-masalah dikemas dan dirumuskan dalam LAS yang telah dikembangkan oleh peneliti sebelumnya yang dapat mengoptimalkan aktivitas dan kemampuan berpikir siswa. Dengan membiasakan siswa bekerja menyelesaikan masalah-masalah kreatif dan beraktivitas dalam menyelesaikan proyek-proyek kerja bersama dapat lebih mengasah kemampuan berpikir kreatifnya. Hal ini juga sudah pernah dibuktikan dalam penelitian yang dilakukan oleh Putra dan Purwasih (2016) bahwa rerata peningkatan prestasi belajar kelas eksperimen dan kontrol masing-masing sebesar 84,57 dan 72,79. Persentase keaktifan mahasiswa kelas eksperimen dan kontrol masing-masing sebesar 70,93\% dan 69,41\%. Dapat disimpulkan bahwa prestasi belajar dan keaktifan mahasiswa yang memperoleh pembelajaran dengan project based learning lebih baik dari pada dengan pembelajaran.

\section{SIMPULAN}

Dari analisis data yang telah dilakukan dan dapat ditarik kesimpulan LAS yang dikembangkan telah memenuhi syarat untuk dijadikan salah satu perangkat pembelajaran yang mampu mengembangkan kemampuan berpikir siswa dan meningkatkan aktivitas kreatif siswa. Validasi soal dalam kategori valid dengan indeks thitung >tTabel yaitu pada masing-masing item soal (1a) 5,18 > 2,0; (1b) 3,88 > 2,04; (2a) 2,84 > 2,04; (2b) 5,18>2,04; (3) 5,05 > 2,04. Dari aspek realibilitas diperoleh indeks $\mathrm{r} 11=0,53$ yaitu kategori sedang; daya beda soal memiliki indeks rata-rata 0,365 yaitu baik, dan tingkat kesukaran soal memiliki indeks yang beragam sehingga soal yang disajikan sudah cukup baik dan layak untuk digunakan dalam pembelajaran di sekolah yang ingin mengedepankan aktifitas kreatif siswa.Aktivitas siswa yang menggunakan LAS dalam pembelajarannya lebih baik dibanding dengan kelas yang tidak menggunkan LAS, rata-rata indeks gain-nya adalah 3,157.

\section{UCAPAN TERIMA KASIH}

Ucapan terimakasih yang sebesar-besarnya peneliti sampaikan pada Kemenristekdikti yang telah memberikan dana untuk mengakomodasi segala kebutuhan penelitian ini Bapak Drs. H. Dahlan Hasibuan selaku kepala sekolah MTs Negeri Rantauprapat dan Ibu Masitah, M.Pd selaku guru bidang studi Matematika di kelas VIII yang telah memberikan kesempatan kepada kami untuk melaksanakan penelitian di sekolah MTs N Rantauprapat. Ketua STKIP Labuhan 
Batu Ibu Halimah Sakdiah Boru Gultom, S.Pd., M.Pd yang telah mendukung pelaksaan penelitian. LPPM STKIP Labuhan Batu yang telah berkoordinasi dalam pelaksanaan dan memberi informasi kepada peneliti dalam menyelesaikan penelitian

\section{DAFTAR PUSTAKA}

Arikunto, S. (2008). Dasar-dasar evaluasi pendidikan. Jakarta: Bumi Aksara.

Bao, L. (2006). Theoritical comparisons of average normalized gain calculation. department of physics, the ohio state university, $191 \mathrm{w}$. woodruff avenue, columbus, ohio 43210, am. $J$. Phys. 74(10).

Dwi, P. H., \& Ratni, P. (2016). Meningkatkan prestasi belajar dan keaktifan mahasiswa melalui project based learning. Diakses melalui https://scholar.google.co.id/citations?user=2y9pmkIAAAAJ\&hl=en pada tanggal 11 September 2018.

Mahmudin, A. (2010). Mengukur kemampuan berpikir kreatif matematis. Makalah Konfrensi Nasional Matematika XV. UNIMA Manado 30 Juni-3 Juli 2010. Yogyakarta: Universitas Negeri Yogyakarta.

Nuraini. (2012). Pengaruh penerapan pendekatan open-ended tehadap tingkat kreativitas, kemampuan pemecahan masalah matematika, dan sikap siswa SMP di aek kanopan. PPs UNIMED.

Prasetyo, B \& Lina, M. J. (2005). M etode penelitian kuantitatif. Jakarta: PT Raja GrafindoPersada.

Purwasih, R. \& Ratna, S. R. (2017). Pembelajaran berbasis masalah untuk meningkatkan kemampuan berpikir kreatif dan self-concept siswa SMP Diakses melalui https://scholar.google.co.id/citations?user=2y9pmkIAAAAJ\&hl=en. pada tannggal 11 September 2018.

Ruseffendi, E.T. (2015). Dasar-dasar penelitian pendidikan dan bidang non-eksakta lainnya. Bandung: Tarsito.

Sugiyono. (2013). Statistika untuk penelitian. Bandung: Alfabeta.

Trianto. (2011). Mendesain model pembelajaran inovatif, progresif, konsep, landasan, dan implementasinya pada kurikulum tingkat satuan pendidikan (ktsp). Jakarta: Kencana.

Trisnawati, I., Pratiwi, W., Nurfauziah, P., \& Maya, R. (2018). Analisis kemampuan berpikir kreatif matematis siswa SMA kelas xi pada materi trigonometri ditinjau dari self confidence. JPMIJurnal Pembelajaran Matematika Inovatif, 1 (3), 383-394. 
Wahidmurni. (2010). Avaluasi pembelajaran (kompetensi dan praktik). Yogyakarta: Nuha Litera. 